\title{
Fungus diseases of field bean in Finland during 1975-1977
}

\author{
Anna-Lissa Ruokola and Mauritz Vestberg \\ University of Helsinki, Department of Plant Pathology, SF-00710 Helsinki 71
}

\begin{abstract}
During 1975-1977, studies were carried out on the fungus diseases of field bean and attempts were made to find, through seed-dusting trials, suitable methods for their control. The fungal flora in a total of 43 seed lots containing $140-200$ seeds each were determined. In addition, plant samples collected from farms where field beans were under cultivation and field bean cultivar trials in seven localities were analysed.

The weather conditions in the growing seasons of 1975 and 1977 were rather exceptional, the former being dry and warm and the latter rainy and cool. Ripe crops were obtained from the control experiments, in which the seeds of 3-4 field bean cultivars were dusted with thiram and benomyl preparations, only in 1975 and 1976.

Ascochyta fabae Speg. was rare in all the seed samples apart from those from LänsiHahkiala, where the degree of infection varied, depending on the cultivar, from 1.3$20 \%$. Botrytis fabae Sard. was rare in the seeds, B. cinerea Pers. ex Fr. quite common in 1976 and especially in 1977. The frequency of the Fusarium fungi were very great on the seeds in 1977, F. culmorum (W. G. Sm.) Sacc. and F. avenaceum (Fr.) Sacc. being the most common.

A. fabae was quite common in the stand samples collected at Länsi-Hahkiala in 1975 and 1976. The chocolate spot-causing agents, B. fabae and B. cinerea, were relatively rare in all years except 1977 , when some cultivars were heavily infested by $B$. cinerea.
\end{abstract}

\section{Introduction}

Cultivation of the field bean (Vicia faba L.) has greatly increased in the Nordic countries since the last decade. Attention has thus been focused on the fungus diseases affecting the cultivation of this plant and on the possibilities of controlling them.

Information about fungus diseases of $V . f a b a$ is available from, for instance, China (Yu 1947), Argentina (Spegazzini 1899), the Soviet Union (ChekalinsKAYA 1963), Iran (KAISER et al. 1967), England (Hewett 1973) and Norway (Sundherm 1973). The most important pathogens of this plant have been found to be Ascochyta fabae Speg., Botrytis cinerea Pers. ex Fr. and B. fabae Sard. (all causing leaf lesions), the last mentioned one being more damaging than B. cinerea (Deverall and Wood 1961, Sundheim 1973).

The cultivation of field bean in Finland is restricted by the length of the growing season. Almost all the foreign cultivars require too long a growing period to be grown under the conditions prevailing in Finland. Breeding work 
using old native varieties from Southeast Finland was therefore started in 1969 at Hankkija's experimental station in Anttila (Hovinen and Kivi 1976). As a result, one improved cultivar is already on the market - the early and small-seeded Mikko. The aim of this study is to determine the species of fungi causing diseases in stands and seeds of field bean under Finnish conditions and their practical importance.

\section{Material and methods}

During $1975-77$ a seed-dusting experiment was carried out on the Viikki Experimental Farm. The field bean cultivers Mikko and the native variety Pirhonen were grown throughout the duration of the experiments, the Swedish varieties Sving and Primus in 1975 only, and Arla in 1976 and 1977. Dusting was carried out with benomyl and thiram preparations, in 1975 with the latter only. The dusting trial was combined in 1975 with a cultivar trial which included the cultivars Arla, the German Herz Freya and Hankkija lines 70006 and 70028 .

When the seeds were checked for healthiness the number of seeds in each lot was found to vary from 140 to 200 . Untreated and surface sterilized seeds were used in 1975, but in subsequent years surface sterilized seeds were used almost exclusively. Seed treatment and incubation was carried out using the same methods as described earlier (RuokolA and Kössi 1977), with slight modifications. The seeds were soaked for $10 \mathrm{~min}$. in NaC1O- $(1 \%$ clorine $)$ solution to destroy saprophytic fungi. In addition to cellulose discs, the seeds were also incubated on weak CM- (12 g/1 corn meal (Difco) +300 ppm streptomycin/l) agar (WCMA) to induce growth of the pathogenic fungi. Plant samples were taken from 7 different localities (Fig. 1), most of them, however being from the experimental field of the Institute of Plant Pathology. Sampling took place during different growth stages.

The microbes were isolated from infected parts of the plants using the method described earlier (Ruokola and Kössi 1977). CMA, PDA (Difco) and Czapec-Dox agar were used as the growth media. Most of the transfers were soaked for one hour in streptomycin solution $(300 \mathrm{ppm} \mathrm{1)}$ to inhibit bacteria.

\section{Weather conditions}

In 1975 the growing season at the southern sites, i.e. Viikki, Tikkurila and Tuusula, was on average very warm with only slight rainfall. The summer was cooler in Länsi-Hahkiala than at the other localities. Total precipitation here during the growing season was lower than normal.

In 1976, the growing season, apart from in May, was cooler than normal. The monthly precipitation sums were also generally lower than normal. The rather heavy rain in Länsi-Hahkiala in July was exceptional.

In 1977, the start of the growing season at Viikki and Tuusula was warmer than normal and less rain than normal fell in Viikki. The rather cool period which started in the middle of the summer continued up until October and precipitation, especially in July, was heavy. 


\section{Results}

\section{Seed-dusting trials}

A combined seed-dusting and cultivar experiment was set up in Viikki in 1975. A total of eight field bean cultivars were used, four in the dusting experiment and four in the cultivar experiment.

Owing to the severe dry period which occurred during the growing season, the early cultivar, Mikko, was harvested already at the beginning of August and the rest during August. Of these, Primus was the latest, its growing period lasting for 103 days. Seed yields were overall rather low, varying from 1128 to $1977 \mathrm{~kg} / \mathrm{ha}$, which is rather a lot less than the normal yield of $3000 \mathrm{~kg} / \mathrm{ha}$. There were no significant differences between the yields, weight of 1000 seeds, volume weight and plant density of the dusted and corresponding undusted test units.

The growing season in 1976 was favourable for the development of Vicia $f a b a$ and hence the seed yields of two of the cultivars used in the dusting experiment, Mikko and Pirhonen, were rather good. The seed yields for Mikko ranged from 4722 to $5026 \mathrm{~kg} / \mathrm{ha}$ and for Pirhonen from 4085 to $4511 \mathrm{~kg} / \mathrm{ha}$. However, no reliable differences as regards yields were found between different treatments. No crop was obtained from Arla owing to the poor germination of the seeds.

The weather conditions prevailing at Viikki in 1977 were unfavourable for the development of field bean since ripened seeds were not obtained from any of the cultivars used in the experiment.

\section{Identifications of the fungi}

Seeds

Altogether a total of 43 seed lots comprising 5040 seeds were analysed. A total of 3315 fungus determinations were carried out on these seeds, either the species or at least the genus to which the fungi belonged being determined (Table 1).

The fungal species and the frequency of occurrence of certain species of fungi varied considerably depending upon site type, cultivar and experimental year. In the analyses carried out in 1975 , the most diverse microflora were found in the seed lots representing the yields obtained in Länsi-Hahkiala and Viikki (Table 2). The most pathogenic fungi, especially A. fabae, were found in the samples from Länsi-Hahkiala. It was most common in the native variety - Pirhonen.

Hardly any $A$. fabae or B. fabae fungi were found in the sample lots from Viikki in 1976 and 1977 (Table 3). On the other hand, B. cinerea and Fusarium fungi were exceptionally common in the seed lots in 1977. The Fusarium fungi determined from all the seeds were, in order of frequency, as follows: F. culmorum (W. G. Sm.) Sacc., F. avenaceum (Fr.) Sacc., F. sambucinum Fuckel, F. poae (Peck) Wollenw., F. semitectum Berk. et Rav., and F. graminearum Schw. 
Table 1. Determined fungi, no. of infected seeds and their percentage out of all seeds investigated.

\begin{tabular}{|c|c|c|}
\hline Fungus & No. & $\%$ \\
\hline Absidia sp. .................... & 1 & 0.02 \\
\hline Acremoniella atra Corda ............................ & 19 & 0.4 \\
\hline Alternaria alternata (Fr.) Keissl. ............................. & 120 & 2.4 \\
\hline 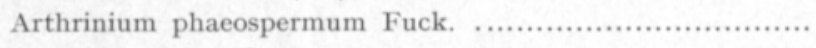 & 5 & 0.1 \\
\hline Ascochyta fabae Speg. . ..................................... & 98 & 1.9 \\
\hline 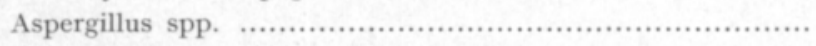 & 31 & 0.6 \\
\hline Aureobasidium pullulans (de Bary) Arnaud $\ldots \ldots \ldots \ldots \ldots \ldots . \ldots . \ldots . \ldots$ & 76 & 1.5 \\
\hline 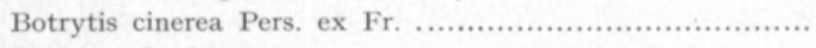 & 177 & 3.5 \\
\hline 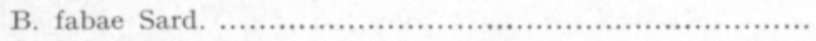 & 6 & 0.1 \\
\hline Cephalosporium spp. .................... & 6 & 0.1 \\
\hline Chaetomium spp. ................................ & 5 & 0.1 \\
\hline 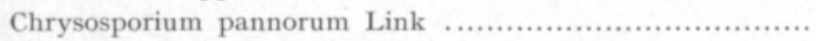 & 93 & 1.8 \\
\hline 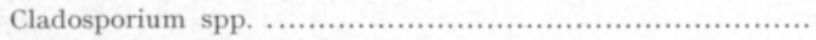 & 947 & 18.8 \\
\hline 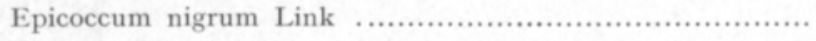 & 1 & 0.02 \\
\hline Fusarium spp. . ................................. & 188 & 3.7 \\
\hline 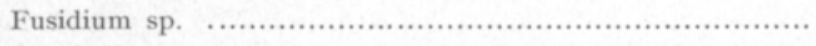 & 1 & 0.02 \\
\hline Gliocladium spp. .................................................... & 4 & 0.1 \\
\hline 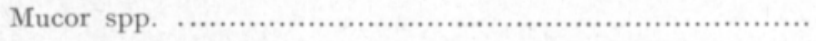 & 290 & 5.8 \\
\hline Ostracoderma state of Peziza ostracoderma Korf .............. & 1 & 0.02 \\
\hline Paecilomyces sp. .......................................... & 1 & 0.02 \\
\hline Penicillium spp. ......................... & 583 & 11.6 \\
\hline Phoma spp. . ....................................... & 133 & 2.6 \\
\hline Rhizoctonia sp. . .................................... & 1 & 0.02 \\
\hline 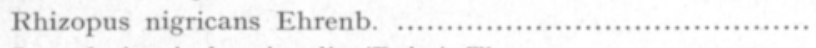 & 433 & 8.6 \\
\hline Scopulariopsis brevicaulis (Bain.) Thom ........................ & 1 & 0.02 \\
\hline Sordaria fimicola (Roberge) Ces. \& de Not. $\ldots . \ldots \ldots \ldots \ldots \ldots . . . . . .$. & 1 & 0.02 \\
\hline 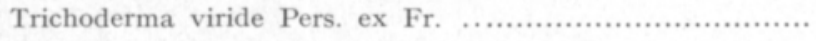 & 57 & 1.1 \\
\hline Trichothecium roseum Link ..................................... & 2 & 0.04 \\
\hline Ulocladium consortiale (Thüm.) Simm. ........................... & 33 & 0.7 \\
\hline Verticillium tenerum (Nees ex Pers.) Link ....................... & 1 & 0.02 \\
\hline
\end{tabular}

In 1977, the Phoma species, P. herbarum Westend and P. eupyrena Sacc., were also isolated from very many samples, in one lot of Mikko seeds about $40 \%$ of the seeds were infected with $P$. eupyrena.

When seed lots with germination percentages of less than 20 were excluded, the germination percentage of the seeds varied from 25 to 100 . In 1975, germination clearly decreased as the proportion of seeds in the seed lots from different cultivars which were infected with fungi or bacteria increased, $r=$ $-0.718^{*}$. In 1976, the correlation between germination percentage and the number of bacteria and fungi isolated from the different cultivars was similar to that found the previous year, $\mathrm{r}=-0.712 *$. The seed lots, apart from Mikko ones, were $100 \%$ infected in 1977 .

Plant samples

Altogether 39 different species of fungi were isolated from the field bean stands, but part of them were classified only at the genus level. The number 
Table 2. Germination of Vicia faba seeds and microflora isolated from yield during years $1973-1975$.

Number of seeds per sample: 1973-1974 40, 1975 120; WCMA medium; untreated seeds and seeds treated with $\mathrm{NaC1O}$ and streptomycin. Besults combined.

\begin{tabular}{|c|c|c|c|c|c|c|c|c|c|c|c|c|}
\hline \multirow[b]{2}{*}{$\begin{array}{l}\text { Site, year } \\
\text { and cultivar }\end{array}$} & \multicolumn{12}{|c|}{ Microorganisms } \\
\hline & 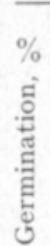 & 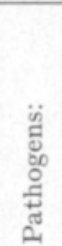 & हूँ & స్ & 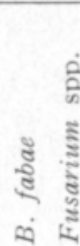 & 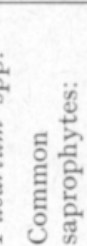 & 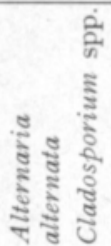 & 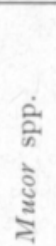 & 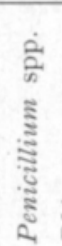 & 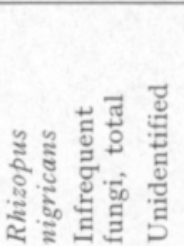 & 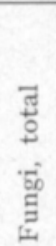 & 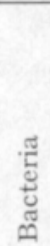 \\
\hline
\end{tabular}

Anttila 1973

$\begin{array}{lr}\text { Primus } \ldots \ldots \ldots \ldots \ldots & 43 \\ \text { Mikko } \ldots \ldots \ldots \ldots \ldots & 95 \\ \text { Herz Freya } \ldots \ldots \ldots & 80 \\ \text { Hja } 70028 \ldots \ldots \ldots & 95 \\ \text { Sving } \ldots \ldots \ldots \ldots \ldots & 100 \\ \text { Arla } \ldots \ldots \ldots \ldots \ldots . & 83 \\ \text { Hja } 70006 \ldots \ldots \ldots . & 88\end{array}$

Pirhonen $1974 \ldots 60$

Viikki 1975

$\begin{array}{llll}\text { Primus } \ldots \ldots \ldots \ldots \ldots & 51 & 1 & 2 \\ \text { Mikko } \ldots \ldots \ldots \ldots \ldots . & 95 & & \\ \text { Pirhonen } \ldots \ldots \ldots \ldots & 83 & 1 & \\ \text { Herz Freya } \ldots \ldots \ldots & 46 & 1 & \\ \text { Hja } 70028 \ldots \ldots \ldots . & 87 & \\ \text { Sving } \ldots \ldots \ldots \ldots \ldots . & 59 \\ \text { Arla } \ldots \ldots \ldots \ldots \ldots \ldots . & 77 & \\ \text { Hja } 70006 \ldots \ldots \ldots . & 91 & & \end{array}$

\begin{tabular}{|c|c|c|c|c|c|}
\hline & 12 & 18 & 1 & 12 & 43 \\
\hline 2 & & 6 & & & 8 \\
\hline & 2 & 9 & & 4 & 15 \\
\hline & 2 & 3 & & 6 & 11 \\
\hline & & 4 & & 4 & 9 \\
\hline & & 1 & 1 & 1 & 3 \\
\hline 1 & & & & & 2 \\
\hline & 1 & 13 & & & 37 \\
\hline
\end{tabular}

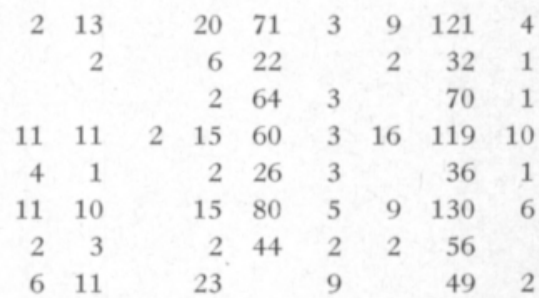

Länsi-Hahkiala 1975

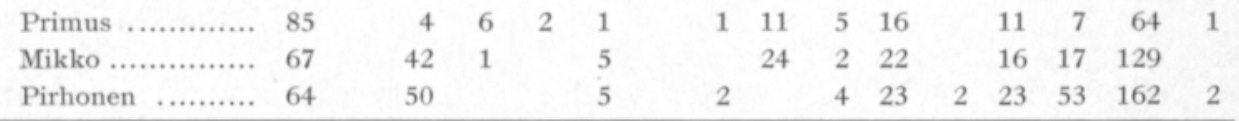

of isolates of the most important fungi was 130 (Table 4). In 1975, leaf sample transfers were taken in the proportion of 2.5: 1 to other types of sample (stem, root and pod); in other years the proportion was 3:2. Alternaria alternata, which is considered to be a saprophyte, was frequently found together with pathogens causing spot diseases. Sometimes, however, it also grew as the only fungus transferred from stems or leaf spots.

In 1977, when the weather conditions prevailing during the growing season were rather unfavourable for the ripening of field bean, the condition of the plants in the dusting experiment was estimated at the end of August using the scale $0-5,0$ indicated a healthy plant and 5 a completely infected plant. The following mean values were obtained:

$\begin{array}{rccc} & \text { Arla } & \text { Mikko } & \text { Pirhonen } \\ 1.50 & 3.45 & 1.95 \\ \text { Cultivars F 7.21* } \text { LSD }_{\mathrm{t}_{0.05}} 1.18 & & \end{array}$


Table 3. Frequency of occurrence of microorganisms in seed crop of dusting experiments at Viikki 1976-1977.

Samples: 100 seeds/test unit, 400/cultivar; WCMA medium, treated with NaC1O and streptomycin.

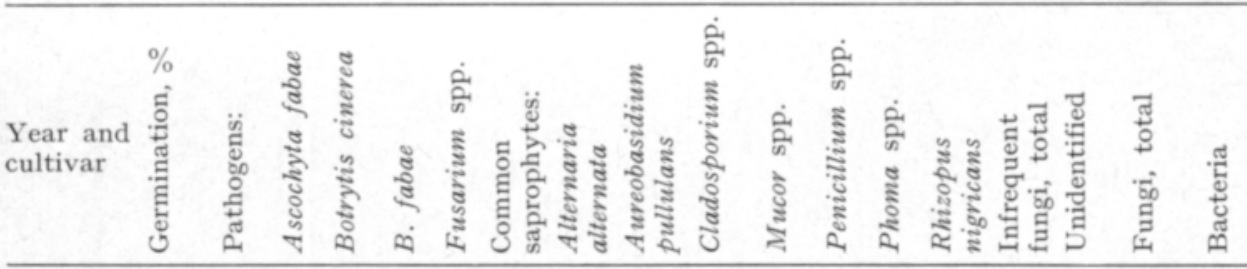

1976

\begin{tabular}{|c|c|c|c|c|c|c|c|c|c|c|c|c|c|c|c|c|}
\hline Mikko & 92 & & 12 & & 5 & 18 & 6 & 59 & 1 & 7 & & & 5 & 12 & 125 & 25 \\
\hline Pirhonen & 75 & 1 & 16 & 2 & 12 & 12 & 21 & 72 & 8 & 13 & & 4 & 10 & 4 & 175 & 83 \\
\hline \multicolumn{17}{|l|}{1977} \\
\hline Arla & - & & 40 & & 72 & & 4 & 236 & 98 & 11 & 18 & 4 & 3 & 5 & 491 & 400 \\
\hline Mikko & 32 & & 65 & & 46 & 21 & 43 & 167 & 39 & 10 & 89 & 1 & 23 & 8 & 512 & 379 \\
\hline Pirhonen & - & & 30 & & 32 & 4 & 2 & 177 & 79 & 3 & 16 & 4 & 3 & 5 & 355 & 400 \\
\hline
\end{tabular}

Table 4. Most important fungi isolated from field bean stands in 1975-1977.

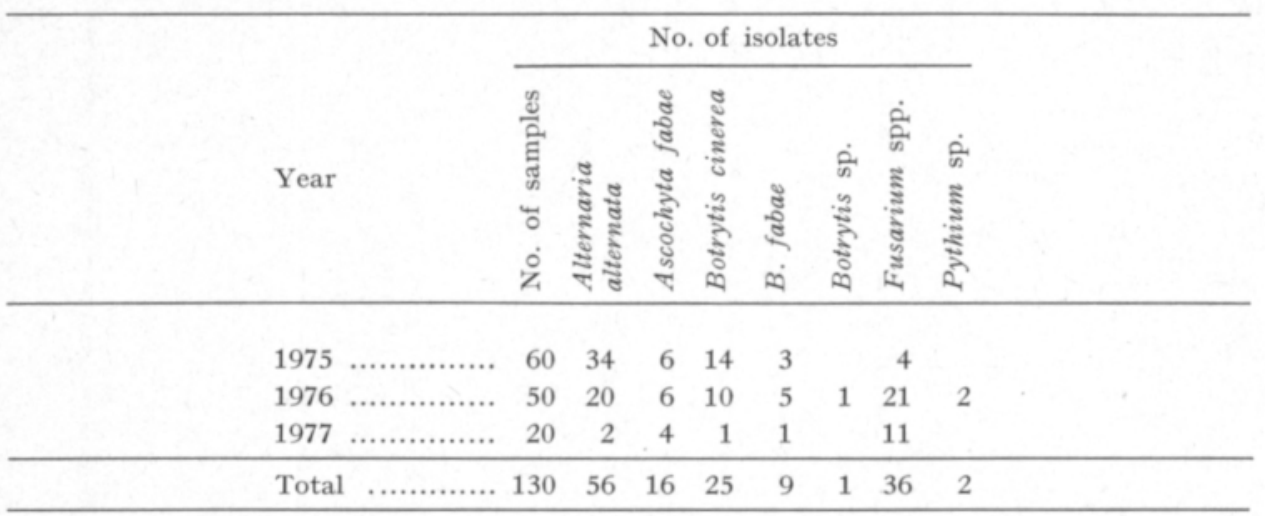

Of the three cultivars, Mikko was the most severely infected with Botrytis fungi and Arla the least. However, these values do not give a completely reliable picture of the susceptibility of these cultivars to disease, because the soil of the different experimental plots was not sufficiently uniform. Mikko clearly did not grow as well as the other cultivars, thus presumably increasing its disease susceptibility. On the other hand, this cultivar was found to be heavily infected by Botrytis fungi at two sites where it was under cultivation, at Tuusula and Sipoo.

The relative proportions of $B$. cinerea and $B$. fabae in the infection of plants in the dusting experiment was determined by randomly selecting one leaf (5-7 leaflets) from each of the experimental plots and placing the leaves on moist filter paper in petri dishes $(\varnothing 13 \mathrm{~cm})$ to induce sporulation. The disease was then partly in the chocolate spot phase and partly in the aggressive phase, 
which appeared as large necrotic spots especially along the edges of the leaves. The leaf samples were examined under the microscope after $6-8$ days. They were found to be almost completely covered with conidiophores of $B$. cinerea; $B$. fabae was found only occasionally. B. fabae occurred, however, in every one of the experimental units where Mikko was grown, almost every one of the Pirhonen ones and on one Arla only. B. fabae fungi were also found in the leaf and pod samples taken from sites at Tuusula where field beans were under cultivation. Rather many conidiophores of this fungus developed in these samples.

A. fabae fungus occurred at five different localities. Fungus damage was the greatest at Länsi-Hahkiala-in 1975 (cf. Table 2) and 1976 and at Jomala experimental station in Åland where samples were taken only in 1977.

The number of $A$. fabae and $B$. fabae isolates obtained from samples taken at different localities were as follows:

\begin{tabular}{|c|c|c|c|}
\hline & Year & Ascochyta fabae & Botrytis fabae \\
\hline Viikki & $1975-1977$ & 6 & 2 \\
\hline Anttila & $1975-1976$ & 2 & 4 \\
\hline Länsi-Hahkiala ......................... & $1975-1976$ & 6 & 3 \\
\hline Tuusula, Riola...$\ldots \ldots \ldots \ldots \ldots \ldots$ & 1977 & 1 & 1 \\
\hline 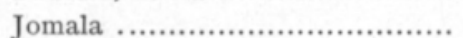 & 1977 & 4 & 0 \\
\hline
\end{tabular}

Neither of these fungi were found in the samples taken at Tikkurila in 1975 and 1976, but almost a quarter of all the Fusarium isolates were obtained from these samples.

Mildew was found on the leaves of Primus cultivars at the end of the growing season in 1975 and proved to be caused by Erysiphe polygoni DC. fungus. Other less important fungi which caused spot disease were as follows: Cercospora cruenta Sacc., Helminthosporium sativum Pamm., King \& Bakke, Phyllosticta viciae (Lib.) Cooke, Septoria viciae Westend and Stemphylium botryosum Wallr.

\section{Pathogenicity of the fungi \\ Ascochyta fabae Speg.}

Spegazzini (1899) was the first to isolate A. fabae from field beans in Argentiina in 1899. Sprague (1929) showed that the fungus he isolated from field bean was a form of $A$. pisi Lib., which resembles $A$. fabae. According to the literature, $A$. pisi, which is a parasite on pea, can also infect field bean (Anon. 1969). A number of researchers (RATschlag 1930, BEAUMont 1950) have named the new fungus Ascochyta sp. which is a parasite only on field bean. According to present-day knowledge, there is no doubt that the Ascochyta fungus in question is identical to that found by Spegazzini.

The disease occurred at the end of the summer. Small brown spots appeared on the leaves of field bean, which gradually enlarged, turned light grey brown, often circular and were separated from the rest of the leaf tissue by a dark brown margin (Fig. 2 a, b). Black pycnidia were formed in the center of the lesions and during damp weather great masses of conidia escaped from the 


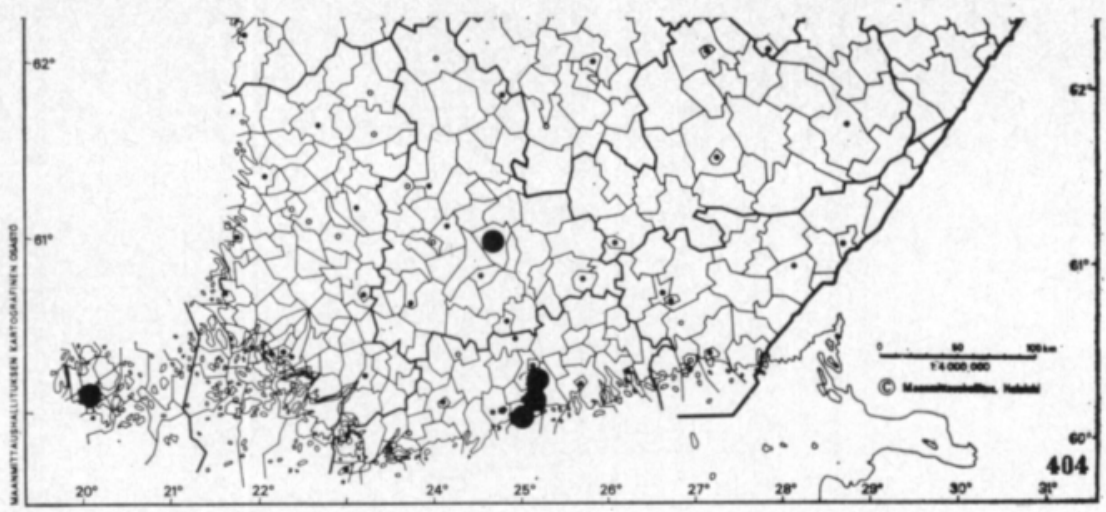

Fig. 1. Geographical origin of the field bean samples.
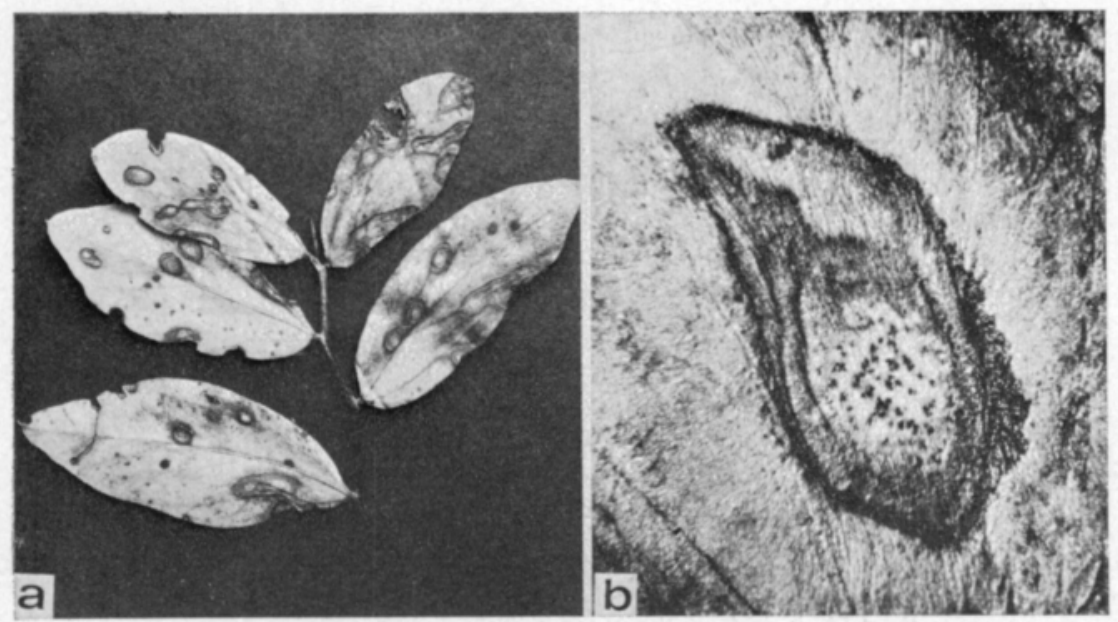

Fig. 2 a. Field bean leaf heavily infected b. Close-up of spot showing pycnidia. with Ascochyta fabae.

ostioles in the pycnidia causing secondary infection in neighbouring parts of the plant. The field bean pods in Viikki were only slightly infected by the primary infection derived from the infected seed used in sowing. It was slightly more common in Länsi-Hahkiala.

On the germination medium the fungus initially covered the infected seed with a white mycelium which later became slightly pink or olive-green.

On CMA the colonies of $A$. fabae were initially white but turned light olive-green as the mycelium aged. On PDA the mycelium was tinted slightly orange and yellow.

The size $(\mu)$ of the pycnidia and conidia of $A$. fabae were as follows:

Pycnidia, Ø Conidia, length $\mathrm{x}$ breadth

From seeds .................. 172-327

CMA, 30 days
$172-327$
-
Mean

$16.6 \times 3.2$

$14.7 \times 3.9$ 
Botrytis cinerea Pers. ex Fr., Botrytis fabae Sard.

SARDiNA (1929) was the first to describe B. fabae on field bean. Paine and LACEy had already earlier (1923) isolated this fungus from field bean, but considered it to be a secondary one. They postulated that the actual disease-causing agent was the bacteria Bacillus lathyri Manns. \& Taubenh. Very many researchers have since published information about the occurrence of B. fabae and B. cinerea on field bean (e.g. Ogilvie and Munro 1947, Åkerman 1955, Gerlach and RudNick 1972, Sundheim 1973).

The large numbers of reddish-brown spots, of from one to a few millimeters in diameter, found on the leaves of field bean (Fig. 3 a) and also later on on

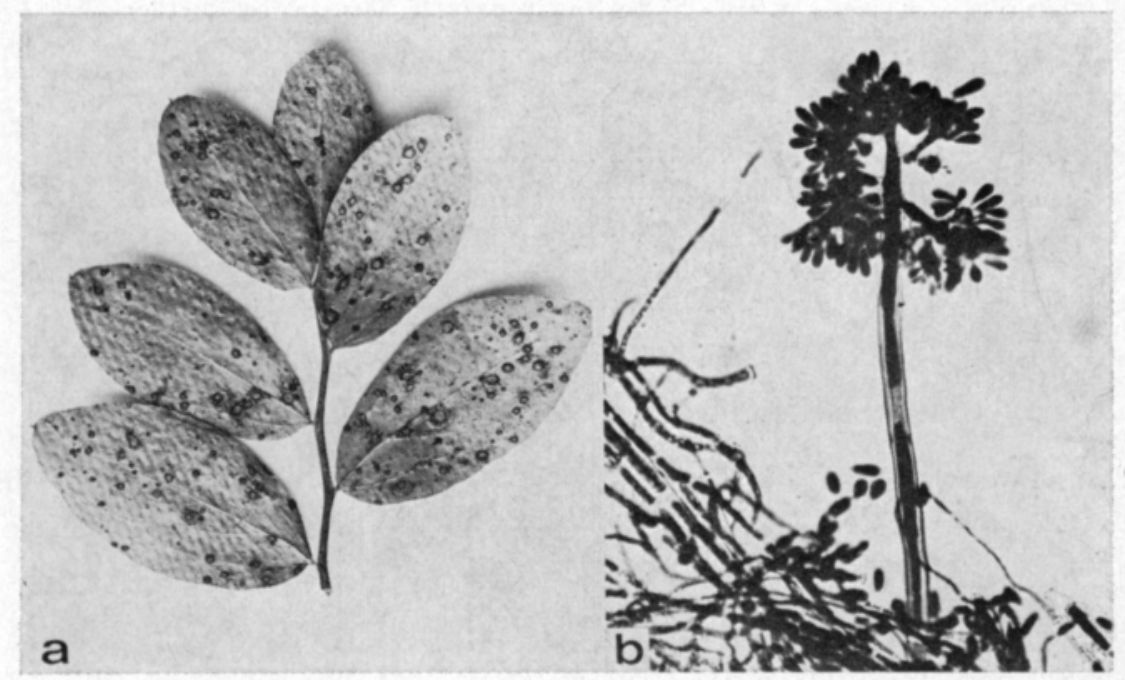

Fig. 3 a. Chocolate spots on a field bean leaf.

b. Conidiophore of Botrytis fabae. $400 \mathrm{x}$.

the stem and pods are characteristic of diseases caused by Botrytis species. The center of the spots were light brown, the edges dark chocolate brown. These chocolate spots represent the harmless stage of the disease (SUNDHEIM 1973). Under certain conditions favourable to the fungus the disease can develop into the aggressive stage, when the plant may be quickly killed-off. In general, however, growth of the fungus stops at the maturation stage (SoDE 1969).

$B$. fabae produced conidia on the surface of the seeds on the germination media and in pure culture, although only in small numbers (cf. Sundherm 1973). In the leaf spots the conidia developed only after being transferred on to moist filter paper.

The fungus initially formed a hyalin, later brownish, loosely packed mycelium on CMA. The conidiophores produced single-celled, oval, colourless conidia (Fig. 3 b). According to Menzinger (1966), the shape, size and occurrence of septa in the conidia varies greatly in this fungus.

The size $(\mu)$ of the conidia of Botrytis species in 30-day old cultures on CMA was:

\begin{tabular}{lrrl} 
& \multicolumn{2}{c}{ Length $\mathrm{x}$ breadth } & Mean \\
B. fabae .......... & $12-20$ & $5-9$ & $16 \times 6$ \\
B. cinerea $\ldots \ldots .$. & $8-12$ & $5-7$ & $9.7 \times 5.7$
\end{tabular}


The sclerotia formed by B. fabae on CMA were smaller and more irregular than those formed by $B$. cinerea.

\section{Fusarium spp.}

F. avenaceum (Noll 1939) and F. solani (Mart.) App. \& Wr. emend. Sn. \& Hans. (YU and FANG 1948) cause root rot-type damage in field bean, and $F$. avenaceum (YU 1944) and F. oxysporum Schl. emend. Sn. \& Hans. have been found to cause wilt disease. In general, these disease forms occur together or else root rot alone. No attempt was made in this study to determine which of these two disease forms was present.

A total of 41 Fusarium isolates were obtained from the stands of field bean, mainly from the stem, especially the lower part. The isolates were divided into the following species on the basis of the systematic division of Воотн (1971, 1977).

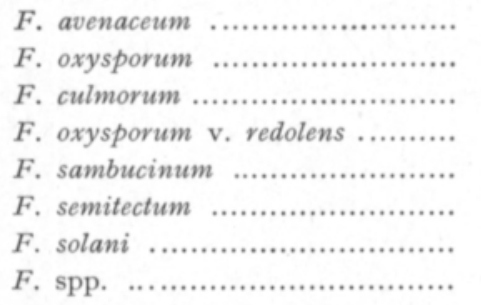

No. of isolates
10
10
8
1
1
1
1
9

The relatively abundant occurrence of $F$. oxysporum in the samples, although it was not found at all in the seeds, indicates that Fusarium infection has mainly been soil or air-borne infection. F. oxysporum occurred most frequently on the base of the stems of yellowish plants, sometimes on the roots. F. avenaceum and $F$. culmorum were likewise isolated from the reddish-brown elongated lesions (Fig. 4), which were sometimes surrounded by a violet ring, at the base and also higher up the stem. The leaves of these infested plants were often completely black when sampled in late summer/early autumn.

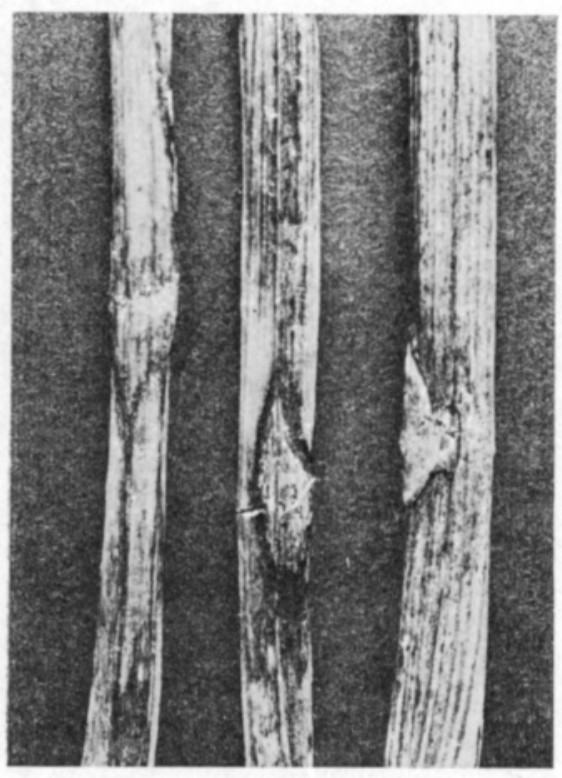

Fig. 4. Spots caused by Fusarium avenaceum and F. culmorum on the stem of field bean. 


\section{Discussion}

Spot disease on field bean caused by $A$. fabae is rather dependant on the air humidity (Beaumont 1950). The total precipitation during the 1975 and 1976 growing seasons at Länsi-Hahkiala was higher than that recorded at the more southerly localities (Fig. 1). A. fabae were also more abundant there than in field bean plants from other places. For instance, the Primus cultivar in Viikki was, owing to the dry period in 1975, only slightly spotted although the seeds used in sowing were severely infected with A. fabae. Secondary infection did not take place that year. However, it is interesting to note that even under such dry conditions the fungus was able to infect the plants via the seeds. The over-wintering of $A$. fabae in infected plant residues remaining in the ground does not appear to be possible in Finland (cf. Sundheim 1973).

$B$. cinerea and $B$. fabae spread in epidemic proportions in the rainy summer of 1977 and caused more damage than A. fabae. Botrytis species can overwinter both in seeds and in infected decaying plants (SODE and JöRgenseN 1974). However, no connection was found between the degree of infection of the seed and the seed crop obtained from them. In fact, according to HARRIson (1978), B. fabae originating from the seeds used in sowing can destroy field bean seedlings, but no significant differences have been found under field conditions between the spottiness of plants developed from seeds infected to differing degrees with this fungus. Besides, B. fabae was no longer present in 9 -month old commercial seed.

In this study seed dusting was not found to have any significant effect on the yield level, which is in good agreement with, for instance, the study carried out in Denmark (NøDdegaArd and Hansen 1972). Despite the fact that according to the Danish and other studies (MAUDE et al. 1969) satisfactory results can be obtained in laboratory tests against $A$. fabae, no compound is available at the present time which would give full protection against diseases spread through the seeds used in cultivation. For this reason the use of clean seed is of prime importance.

\section{REFERENCES}

Anon. 1969. A list of new diseases in Iran. Iran J. Pl. Path. 5: 64-65.

Beaumont, A. 1950. On the Ascochyta spot disease of broad beans. Trans. Brit. Mycol. Soc. 33: $345-349$.

Воотн, C. 1971. The genus Fusarium. 235 p. Kew, Surrey, England.

- 1977. Fusarium. Laboratory guide to the identification of the major species. 58 p. Kew, Surrey, England.

Chekalinskaya, N. I. 1967. (In Russian). Summary: Diseases of broad bean. Bot. Issled., Minsk 5: 210-216. (Ref. Rev. Appl. Mycol. 46: 50.)

Deverall, B. J. \& Wood. R. K. S. 1961. Infection of bean plants (Vicia faba L.) with Botrytis cinerea and Botrytis fabae. Ann. Appl. Biol. 49:461-472.

GerLAch, W. \& Rudnick, M. 1972. Ein bemerkenswertes Auftreten der Schokoladenfleckenkrankheit der Ackerbone in Schleswig-Holstein (Erreger: Botrytis fabae Sardin̄a). Nachr. bl. Deutsch. Pfl. schutzd. 24: 115-117.

Harrison, J. G. 1978. Role of seed-borne infection in epidemiology of Botrytis fabae on field beans. Trans. Brit. Mycol. Soc. 70:35-40. 
Hewetr, P. D. 1973. The field behaviour of seed-borne Ascochyta fabae and disease control in field beans. Ann. Appl. Biol. 74: 287-295.

Hovinen, S. \& Kıvı, E. 1976. Härkäpapu. Hankkijan kasvinjalostuslaitos. Siemenjulkaisu 1975: 64-66.

Kaiser, W. J., Mueller, K. E. \& Danesh, D. 1967. An outbreak of broad bean diseases in Iran. Pl. Dis. Rep. 51: 595-599.

Maude, R. B., Vizor, A. S. \& Shuring, C. G. 1969. The control of fungal seed-borne diseases by means of thiram seed soak. Ann. Appl. Biol. 64: 245-257.

Menzinger, W. 1966. Zur Variabilität und Taxonomie von Arten und Formen der Gattung Botrytis Mich. 1. Unțersuchungen zur kulturbedingten Variabilität morphologischer Eigenschaften von Formen der Gattung Botrytis. Zbl. Bakt. 120: 141-178.

Nol, W. 1939. Untersuchungen über Fuss- und Welkekrankheiten bei Leguminosen. Z. Pfl.krankh. Pfl. schutz 49: 385-431.

NøddegaArd, E. \& Hansen, E. 1972. Førsøg med plantebeskyttelsemidler i landbrugs- og specialgrøder 1970. Tidskr. Pl.avl. 76: 658-681.

Ogilvie, L. \& Munro, M. D. 1947. Occurrence of Botrytis fabae Sard. in England. Nature 160: 96.

Panne, S. G. \& LAcey, M. S. 1923. Studies in bacteriosis. 4. Streak diseases of broad beans. Ann. Appl. Biol. 10: 194-203.

Ratschlag, H. 1930. Zur Spezialisierung der auf Vicia faba parasitierenden Ascohyta. Phytopath. Z. 2: 493-501.

RuокоцA, A.-L. \& Kössı, L. 1977. Fungus diseases of pea seeds and stands in Finland. Acta Agric. Scand. 27: 97-104.

SARdiÑ A, J. R. 1929. Una nueva especie de Botrytis que ataca a las Habas. Mem. R. Soc. Espanola Hist. Nat. 15: 291-295.

SodE, J. 1969. Sygdomme og skadedyr på hästebønner. Landbonyt 23: 108-112.

- \& Jørgensen, J. 1974. Sammanhaengen mellem sygdomsforekomst $i$ udsaed af hestebønne, på planterne $\mathrm{i}$ marken og i det høstede frø. Statsfrøkontr. ber. 103: 99-106.

Spegazzini, C. 1899. Fungi Argentini. An. Mus. Nac. B. Aires 6: 81-367.

Sprague, R. 1929. Host range and life-history of some leguminous ascochytae. Phytopath. 19: $917-932$.

Sundherm, L. 1973. Botrytis fabae, B. cinerea and Ascochyta fabae on broad bean (Vicia faba) in Norway. Acta Agric. Scand. 23: 43-51.

YU, T. F. 1944. Fusarium diseases of broad bean. 1. A wilt of broad bean caused by Fusarium avenaceum var. fabae n. var. Phytopath. 34: 385-393.

- 1947. Ascochyta blight and pod spot of broad bean in China. Phytopath. 37: 207-214.

- \& FANG, C. T. 1948. Fusarium diseases of broad bean. III. Root rot and wilt of broad beans caused by two new forms of Fusarium. Phytopath. 38: 587-594.

Åkerman, A. 1955. Årsberättelse över Sveriges Utsädesförenings Tidskrift 65: 111-187.

Ms received October 24,1978 


\section{SELOSTUS}

\section{Härkäpavun sienitaudit Suomessa vuosina 1975-1977}

Anna-Lissa Ruokola ja Mauritz Vestberg

Helsingin yliopiston kasvipatologian laitos, 00710 Helsinki 71

Vuosina 1975-1977 suoritettiin tutkimuksia härkäpavun sienitaudeista sekä pyrittiin peittauskokein selvittämään niiden torjuntaa. Tutkittiin 140-200 siementä käsittävän yhteensä 43 erän sieniflora. Lisäksi analysoitiin kaikkiaan 7:1tä eri paikkakunnalta härkäpavun lajikekokeista ja yksityisiltä viljelyksiltä kerättyjä kasvinäytteitä.

Kasvukaudet 1975 ja 1977 olivat sääsuhteiltaan sangen poikkeuksellisia, edellinen kuiva ja lämmin, jälkimmäinen sateinen ja viileä.

Torjuntakokeista, joissa 3-4 härkäpapulajiketta peitattiin tiraami- ja benomyylivalmisteilla, saatiin tuleentuneita satoja vain vuosina 1975 ja 1976 . Luotettavia eroja peitattujen ja vastaavien peittaamattomien koejäsenten satojen välillä ei tällöin esiintynyt.

V. 1975 tutkituista siemeneristä oli Primus eniten sienten saastuttama, sen jälkeen Pirhonen ja alhaisin saastuneisuusprosentti oli Arlalla. V. 1976 oli Pirhonen Mikkoa saastuneempi sekä sienten että bakteerien suhteen. V. 1977 Arla, Mikko ja Pirhonen olivat 100 \%:sti sienten ja bakteerien turmelemia.

Ascochyta fabae Speg. oli harvinainen muissa, paitsi Länsi-Hahkialan siemennäytteissä, joissa saastuneisuusprosentti oli lajikkeesta riippuen 1.3-20; Pirhonen oli saastunein. Botrytis fabae Sard. oli siemenissä harvinainen, B. cinerea Pers. ex Fr. melko yleinen 1976 ja varsinkin 1977, jolloin Mikko-lajikkeen siemenistä oli $16 \%$ saastunut. Fusarium-lajeista, joita esiintyi siemenissä runsaasti v. 1977, olivat yleisimmät $F$. culmorum (W.G. Sm.) Sacc. ja $F$. avenaceum (Fr.) Sacc.

A. fabae oli sangen yleinen L.-Hahkialan kasvustonäytteissä vv. 1975-1976. Suklaalaikun aiheuttajat $B$. fabae ja $B$. cinerea olivat suhteellisen harvinaisia muina koevuosina paitsi 1977 , jolloin $B$. cinerea saastutti voimakkaasti varsinkin Mikko-lajiketta. 